\title{
The future of England's healthcare lies in the hands of competition lawyers
}

The government's revised regulations on competition in the NHS have removed much of the initial clarity and are ambiguous in several places

\section{Martin McKee professor of European public health, London School of Hygiene and Tropical Medicine}

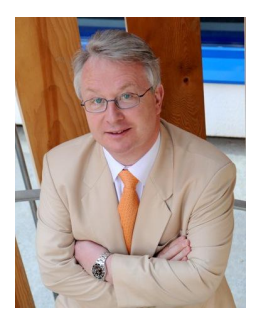

The Health and Social Care Bill that the government sprung on an unsuspecting electorate in January 2011 attracted much criticism but had the advantage of clarity of purpose. It envisaged a competitive market in which healthcare would be purchased from any willing provider, regardless of the provider's experience.

Faced with widespread criticism that it could lead to privatisation of most healthcare, fragmentation, and huge administrative costs that would suck resources from the care of patients, the government paused to engage in a "listening exercise." Many words were changed in the revised bill; any "willing" provider became any "qualified" provider, albeit unspecified. New lines of accountability were introduced but confounded those seeking to represent them on paper. A widespread view was that the revisions had created confusion rather than clarity. The critics maintained that the bill's fundamental goal of privatisation remained and predicted that this would become apparent when the government published the regulations needed to implement it.

In February 2013, only a few weeks before the act was due to come into force, the regulations on competition were laid before parliament. ${ }^{12}$ The critics were right. All services must be opened to competition. The new clinical commissioning groups could not pick and choose. This was not what the act's few remaining supporters had agreed to.

Those supporters had believed the assurances made by ministers seeking support from Liberal Democrat politicians to get the bill passed. When speaking of private provision, ministers invariably referred to small charities providing niche services and not large corporations without previous involvement in healthcare. The ministers accused their critics of scaremongering, offering reassurances that the bill didn't really mean what it said. The former health secretary Andrew Lansley said that it was "absolutely not the case" that commissioners would be forced to put services out to tender. The health minister Simon Burns said that it was not the government's intention to "impose compulsory competitive tendering requirements on commissioners, or for Monitor [the competition regulator] to have powers to impose such requirements." In the House of Lords, Earl Howe emphasised that there would be "no legal obligation to create new markets."

The publication of the regulations largely escaped media attention, conveniently distracted by the Mid Staffordshire affair. But a petition by the campaigning group 38 Degrees attracted over 350000 signatures, 1000 health professionals wrote to the Daily Telegraph, and the Liberal Democrat MP Andrew George called for the regulations to be withdrawn.

The government resorted to a tried and tested formula: pause and listen. Ministers portrayed themselves as victims of careless parliamentary drafting, reporting surprise at what had been written, which suggested that they had laid the regulations before parliament without having first read them. This evoked memories of the shock expressed by Captain Renault in Casablanca when he "discovered" gambling taking place in Rick's bar. Then the ministers claimed that the regulations were much the same as what had been put in place by the last Labour government, provoking the question of why a 300 page act had been needed. Yet the regulations were crystal clear and entirely consistent with the act. The inconsistency was between the ministers' reassurances and both the act and the regulations.

So how do the new regulations differ? There is a nod to integration, although not as one of the three objectives that commissioners must pursue (securing needs, improving quality, and promoting efficiency) but only as one way in which they might do so. A paragraph clarifying the extremely limited circumstances in which commissioners could offer a contract without competition has been deleted, with nothing in its place. 
The section prohibiting anticompetitive behaviour now has an exception for when integration or cooperation can be shown to be in the interests of patients, although without guidance as to how this would be established. Finally, Monitor is prevented from ordering a commissioner to open up a service to competition. Many will, no doubt, be reassured that the original regulations were an innocent mistake now corrected.

Or maybe not. The revisions have removed much of the initial clarity and, in several places, are ambiguous. In one place anticompetitive behaviour is forbidden unless it is in "the interests of" service users-in another unless it is "necessary" to achieve intended outcomes for them. These are not the same. Commissioners must achieve "best value," which is unspecified and, as the experience of tendering for the west coast rail franchise showed, a challenge to define. There is no requirement to consider stability of existing providers, and, arguably, this is forbidden. Commissioning is on behalf of users, not the population, thus excluding those whose needs are not already met.

So where now? For the government's changes to achieve their fundamental goal it was never necessary for all care to be privatised, only those bits from which large corporations could make adequate profits. However, the contradictions within the regulations and with the act create a magnet for competition lawyers, including some of the peers who supported the act. The result is that the future of healthcare in England lies in the hands not of politicians and professionals but of competition lawyers. Clinical commissioning groups may no longer fear Monitor but will think twice before invoking the wrath of one of the large corporations now moving into healthcare. With legal and contracting teams many times larger than those available to the commissioners, it is they who will be the ultimate arbiters of the shape of healthcare.

Acknowledgment: I am grateful to Lucy Reynolds for sharing her encyclopaedic knowledge of the Health and Social Care Act and to the CCGWatch blog (https://ccgwatch.wordpress.com) for its work exposing what is happening to the NHS.

Competing interests: None declared.

1 Kmietowicz Z. Doctors say rewritten rules on competition do not go far enough. BMJ 2013;346:f1634.

2 lacobucci G. Vast majority of NHS services must go out to tender, health minister says. BMJ 2013;346:11322.

Cite this as: BMJ 2013;346:f1733

C BMJ Publishing Group Ltd 2013 